\title{
Semiotics of Politics: Dialogicality of Parliamentary Talk
}

Jaakko Turunen

Uppsala: Acta Universitatis Upsaliensis 2015

396 sider. ISBN 9789155491314

Anmeldt av Audun J. Mørch [PhD, førsteamanuensis i russisk litteratur, Universitetet i Oslo, a.j.morch@ilos.uio.no]

Jaakko Turunens Semiotics of Politics: Dialogicality of Parliamentary Talk er en grundig og innovativ doktorgradsavhandling i statsvitenskap fra Uppsala Universitet. Avhandlingen presenterer en analyse av to parlamentsdebatter, en fra Slovakia og en fra Polen. Den slovakiske debatten fra 2009 omhandler en endring av landets språklov, og den polske fra 2010 en lov om likestilling mellom kjønnene, nærmere bestemt et krav om at valglister skal inneholde minst 50\% kvinnelige kandidater. Som materiale bruker forfatteren stenografiske utskrifter av debattene, og han analyserer disse som tekst.

Det innovative $\mathrm{i}$ avhandlingen er at Turunen benytter seg av andre teorier enn det som er vanlig i statsvitenskap. Nettopp det at Turunen betrakter sitt materiale som tekst gjør det mulig for ham å vende seg mot semiotikk og litteraturvitenskap. Forfatteren argumenterer overbevisende for at de analyseredskaper statsvitenskapelig diskursanalyse rår over ikke er tilstrekkelige for den analysen han har satt seg fore å gjennomføre, men at han derimot finner disse redskapene hos Gadamer, og hos de to russerne Bakhtin og Lotman, som er kjente navn i litteraturvitenskap og semiotikk. Turunen ønsker å forstå dynamikken bak parlamentsdebattenes utvikling. Han legger som premiss at for å greie dette kan han ikke bruke analyseredskaper som er innrettet mot å uteske de ulike talernes ståsted og intensjoner, han må heller flytte fokus til hvordan argumentene forstås, fortolkes og imøtegås av tilhørere og meddebattanter. På samme måte som i litteraturvitenskapen flytter han fokus fra forfatteren til leseren.

For denne anmelderen, som har faglig bakgrunn nettopp i russisk litteratur og litteraturteori, er dette egentlig ikke så oppsiktsvekkende. Det synes tvert imot som et opplagt og naturlig grep som tiden har vært overmoden for. I Russland har litteraturvitere tross alt analysert diskurser $\mathrm{i}$ hundre år, helt siden de russiske formalistene kastet vrak på den positivistiske metoden. De russiske formalistene synes det var fåfengt å diskutere spørsmål som hvorvidt dikteren Pusjkin røkte, og begynte heller å analysere litterære tekster for å finne ut på hvilke måter en litterær tekst skiller seg ut fra andre typer tekst. Til neste år er det hundre år siden formalismens kanskje aller mest kjente essay, Viktor Sjklovskijs Kunsten som grep (Iskusstvo kak priëm) kom ut. Verken Bakhtin eller Lotman regnes som formalister, 
men den russiske formalismen er ikke desto mindre en forutsetning for disse forskernes senere arbeid.

Mikhail Bakhtin er kjent som opphavsmannen til begreper som polyfoni, dialogisme, karnevalisme og kronotop. Turunen benytter seg først og fremst av dialogbegrepet, men også begrepet polyfoni er relevant. Bakhtin argumenterte for at Dostojevskij var «oppfinneren» av den polyfone roman, det vil si en roman der forfatteren gir avkall på å være «gud» i sitt fiktive univers og i stedet slipper romanpersonene fri og lar dem utvikle sine synspunkter og etter hvert sine ideologier i henhold til deres egen indre logikk, uavhengig av forfatterens egen posisjon. Dette er en spennende teori, men mange forskere har senere stilt seg kritisk til Bakhtins polyfonibegrep. Vel har Bakhtin rett i at Dostojevskij gir romanpersonene en hittil ukjent, ny frihet til å utvikle sine ideologier selvstendig, men det er likevel slik at Dostojevskij beholder siste ord: han bestemmer fremdeles over romanpersonenes skjebne og dermed feller han også en dom over deres ideologier. Bakhtin forlot da også polyfonibegrepet og gikk over til å snakke om dialog og språkets iboende dialogisitet.

Turunens materiale er derimot ikke romaner ført i pennen av en enkelt forfatter. Hans materiale er ikke en roman, men utskrifter av en debatt med mange opphavsmenn og -kvinner. På et vis kan man si han leser debattutskriftene som en polyfon roman, men i motsetning til en roman er disse tekstene uten tvil genuint polyfone. Dette er et ganske elegant grep fra Turunens side!

Viktigere er imidlertid dialogbegrepet. Bakhtin tar i utgangspunktet til motmæle overfor den strukturalistiske språkforståelsen vi har arvet etter Saussure. Språkets grunnenhet er ikke setningen, som er et kunstig og konstruert begrep. Grunnenheten er derimot utsagnet (vyskazyvanie). Ordene vi bruker henter vi ikke ut av en ordbok, eller et paradigme, som Saussures langue, «men ut av andre menneskers munner». Språket læres gjennom dialog, og er også grunnleggende dialogisk. Det innebærer at det enkelte utsagn aldri kan forstås hvis det rives ut av sin kontekst. Utsagnet er alltid et svar på et tidligere utsagn fra en eller flere dialogpartnere, og ikke minst forsøker den som taler eller skriver ifølge Bakhtin å foregripe senere utsagn fra andre. Turunen demonstrerer at det er vanskelig å forstå både de enkelte debattinnlegg og ikke minst de retningene debatten tar uten denne språkforståelsen.

Det er særlig den slovakiske debatten om språkloven han analyserer med utgangspunkt i Bakhtin. Et hovedpoeng er at en representant for den ungarske minoriteten i Slovakia tolker lovforslaget som en trussel mot den ungarske minoritetens borgerrettigheter, og den videre debatten tar i høy grad farge av dette. Debatten, som på overflaten handler om en språklov, handler på underliggende plan om Slovakias historie og multietnisitet, og det enkelte utsagn bærer tydelig preg av dette. En uuttalt diskurs påvirker den som uttales. Dette minner i det hele tatt ganske mye om Bakhtins analyse av dialogiske sekvenser i Dostojevskijs Idioten og Brødrene Karamazov, noe Turunen imidlertid ikke påpeker. Debatten ender med at lovendringen vedtas, blant annet fordi representanten for den ungarske minoriteten ikke får støtte fra andre og mindre minoriteter.

Mens den slovakiske språkdebatten var preget av sterke historiske og kulturelle slagskygger, representerte den polske debatten om likestillingsloven tvert imot noe 
helt nytt i polsk politikk. Delegatene manglet i det store og hele mentale knagger å henge problemstillingen og argumentene på, slik jeg forstår Turunens argumentasjon. For å forstå denne debatten bruker Turunen hovedsakelig Lotmans teori om semiosferen. Semiosfæren er en forståelseshorisont med vekt på det som ut fra en gitt kulturbakgrunn gir mening og har en betydning. Turunen argumenterer for at debatten grunnleggende falt utenfor delegatenes semiosfærer. Delegatene løser dette problemet med en form for oversettelse (perevod) av argumentene til et «språk» de er fortrolig med - og som et resultat blir likestillingsspørsmålet blant annet relatert til Polens kommunistiske fortid.

Dette er slik Lotman forstår meningsutveksling (dialog) i et levende språk. De to talende vil normalt ha delvis, men aldri helt sammenfallende forståelseshorisont. Hvis det derimot forholder seg slik at forståelseshorisontene knapt er sammenfallende i det hele tatt, vil ikke oversettelse lenger være mulig: det oppstår det Lotman kaller eksplosjon (vzryv) og et resultat av dette kan være at det oppstår inkompatible argumenter for samme syn, for eksempel at man på den ene siden ikke ønsker loven fordi den ikke vil gi det tiltenkte resultat, og at man på den annen side ikke ønsker den fordi den representerer en slags attergløyme fra den kommunistiske fortiden og derfor ikke er demokratisk. (Mye av debatten kom til å dreie seg om demokrati som sådant.) Turunen argumenterer for at slike «eksplosjoner» preger den polske debatten. Uansett lander man på et kompromiss der det vedtas at 35 prosent - ikke 50 prosent - av navnene på alle valglister skal være kvinner. Dette kompromisset er ifølge Turunen et klart nederlag for både motstanderne og tilhengerne av lovforslaget.

Turunens analyse er svært grundig, slik man også forventer av en doktorgradsavhandling. I innledningskapitlene gjennomgår han en lang rekke teoretikere innenfor diskursanalyse og konversasjonsanalyse og grunngir på en overbevisende måte hvorfor disse kommer til kort i forhold til den oppgaven han har satt seg. Han kjenner dessuten sin Bakhtin og Lotman, og ikke minst har han evnen til å tilpasse og bruke teoriene til sitt eget materiale på en smidig, «sømløs» måte. Svært grundig gjennomgår han også materialet, det vil si parlamentsutskriftene, og gjentar ofte sitatene for å belyse dem fra flere sider.

Gjennom to lange kapitler siterer Turunen fra de to debattene og kommenterer utsagnene underveis. Imidlertid forundres man noe over at han knapt lar disse underveiskommentarene være informert av Gadamers, Bakhtins og Lotmans teorier dette er noe Turunen i hovedsak sparer til slutt. Resultatet av dette er at avhandlingen synes å ha blitt lenger enn det som strengt tatt hadde vært nødvendig for å overbevise om at konklusjonene er verdifulle og korrekte. Andre lesere med større interesse av selve saksinnholdet i debattene vil kanskje tenke annerledes om dette. Ikke desto mindre tror jeg en strammere komposisjon ville bidratt til å holde leserens interesse på et jevnt høyt nivå gjennom hele boken.

Jeg tror neppe det kan være noen tvil om at Turunen gjennom sin avhandling har bidratt til å belyse politiske prosesser i Slovakia og Polen. Gjennom sin metode og innovative bruk av russisk tekst- og litteraturteori i en statsvitenskapelig kontekst har han forhåpentlig også gitt andre forskere redskaper de trenger for å analysere de politiske debattenes utvikling og dynamikk. Spesielt avslutningskapittelet var definitivt inspirerende lesning. 